SF 233

C $2 R 8$ 


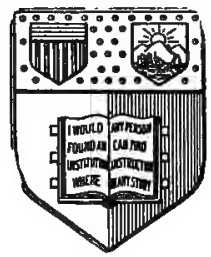

Anvur 罗ark

State Crallege af Anritulture

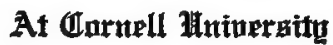

Jthara, ‥

Tilhrary 


\title{
THE
}

\section{DAIRYING INDUSTRY}

$\mathbf{B X}$

\author{
J. A. RUDDICK
}

Dairy and Cold Storage Commissioner

\section{$\triangle$ I ISCTERE DELIVERED BEFORE THE \\ MAY COURT CLUB \\ OTTAWA}

FEBRUART 21, 1908

OTTAWA

GOVRRNMEANT PRLNTLNG BUREAU

1908 


\section{Cornell University Library}

The original of this book is in the Cornell University Library.

There are no known copyright restrictions in the United States on the use of the text. 


\section{THE}

\section{DAIRYING INDUSTRY}

B Y

J. A. RUDDICK

Dairy and Cold Storage Commissioner

A IECTURE DELIVERED BEFORE THE

M A Y COURT C L UB

OTTAWA

February 21, 1908

OTTAWA

GOVRRNMHNT PRINTING BOREAU

1908

a.s 



\section{THE DAIRYING INDUSTRY}

$\mathrm{O}^{\mathrm{NE}}$ would need to have a more fertile imagination than I have, to be able to put much poetry into a description of the dairy industry. It is, however, not only one of the greatest industries in Canada from a material point of view, but it is one of the great industries of the world. The dairy industry supplies all civilized people with at least two of their most indispensable articles of food. There may not be many people induced to engage in the business of dairying from a pure love of it, but it cannot be denied that it does offer attractions to those who are obliged to consider the money-getting possibilities of whatever line of effort their energies are employed in.

There are not many persons in this audience, or in the whole Dominion for that matter, who do not derive, either directly or indirectly, some benefit from this great industry which has contributed so largely to the prosperity of Canadian agriculture. This assertion will be the more readily believed when I state that the total value of the products of Canadian dairies, including milk, butter, cheese and condensed milk, amounts to something like $\$ 100,000,000$ annually.

A very important point in this connection is the fact that while we recover, with the aid of the gentle cow, this large amount of wealth from mother earth, by the transmutation of pasturage and fodder crops into milk, the soil is not impoverished in the process, but on the contrary, is left in better condition every year to produce another $\$ 100,000,000$. If 
you dig a million dollars out of a gold mine, you have nothing left but a hole in the ground, and I am told that you are much surer of the hole in the ground than you are of the million dollars. In a country like ours where agriculture is the true basis of all wealth, this question of the conservation of soil fertility is of fundamental importance.

In view of these facts, I have no further apology to offer on behalf of the dairy industry.

A broad application of the term, "dairying industries," would include milk production, the millk supply of town and cities, the manufacture of butter, cheese and condensed milk and the numerous by-products obtained from the casein of milk, such as substitutes for ivory and celluloid, adhesives, woodfillers, paint, pencil erasers, toilet cream, \&c., \&c. But knowing the short time at my disposal, and believing that the patience and endurance of the members of the May Court Club and their friends must have limitations, I am obliged to use the term in a more restricted sense this evening. I shall confine myself, therefore, to a brief reference to the two great branches of the industry, namely, the manufacture of butter and the manufacture of cheese, with particular reference to the butter and cheese which is made in factories. It has been the common practice to base all estimates of our progress on the factory end of the business, because the home end of dairying is such an unknown quantity that accurate figures are not obtainable, although it is estimated that the milk which is used for direct consumption, and the butter which is made on farms have a value which is at least double the value of the butter and cheese made in factories.

The use of millk and its products as foods for man, dates back to the very earliest times. We find frequent mention of butter and cheese in the early books of the Bible. Cheese was known to the Greeks before the time of Homer, and Cæsar 
relates that the German tribes supplied the Romans with cheese in his day.

Tradition says that butter was discovered by the nomadic tribes of the East, who found that it was produced by the agitation which mills received when transported long distances on the backs of camels. It is said that in Arabia, even to this day, a sort of oily butter is procured by placing the milk in a vessel made from the skin of an animal, and shaking it to and fro suspended from the limb of a tree or other convenient support.

Butter, as we know it, consists of the fat of mill, in solid form, mixed with a certain percentage of water, which may vary according to the skill or intention of the buttermaker, but 12 to 14 per cent is considered to be about the right proportion. Sixteen per cent of water is the legal limit in this country. The process of buttermaking is practically the same wherever scientific methods are followed, and it requires an expert to detect the slight differences of flavour and texture which may be found in well made samples of butter brought together from the ends of the earth. Of course, there is good and bad butter to be found everywhere, and it is the proportion of the two kinds produced in any country, that makes or mars its reputation in this respect, rather than any distinctive quality or characteristic in the product which may be traced to locality of origin.

Cheese is made by precipitating the protein compounds of milk with rennet. The curd which is thus formed holds the fat of milk mechanically, and a certain amount of the water is also retained. A Canadian cheddar cheese, for instance, consists, roughly speaking, of one-third fat, one-third protein or casein compounds, and one-third water.

The art of cheese-making is infinitely more intricate and difficult than that of butter-making. It deals with several 
constituents of the milk, two of which, the sugar and the casein, unlike the comparatively inert and stable fat, are peculiarly subject to bio-chemical changes, as yet not fully understood or studied by the chemist and the bacteriologist.

It requires only slight modifications of the process of cheesemaking to produce marked differences in the finished product. As a result, there are probably 100 distinct different varieties of cheese made in various parts of the world, and at least 25 well-known classes, varying greatly in appearance, texture and flavour-particularly in flavour.

They vary in texture from the Schabzieger of the Swiss Alps, so hard that it must be grated, or rasped, as the name suggests, to the soft and creamy French cheese, like Brie or Camembert; in the matter of flavour, there is the mild and genteel Cheddar on the one hand, and the loud and vigorous Limburger on the other; and as for size, they range from the dainty Neufchatel, a few ounces in weight, to the ponderous Gruyère which may weigh over 100 lbs.

While the preparation of cheese as an article of food is undoubtedly one of the oldest of the technical arts, the science of cheese-making is of very recent origin. Until only twenty or thirty years ago, our knowledge of the art was almost wholly empirical, having been handed down from father to son, or more correctly speaking, from mother to daughter, each generation adding its quota of experience to the rules which then did duty for the more exact knowledge that is available to the cheesemaker of the present day.

The brilliant researches and discoveries of Pasteur, although they did not include a study of milk, nevertheless blazed the track along which other scientists have followed to show us the why and the wherefore of many of the changes that take place in milk and its products. We know now that the profound changes which result from milk fermentations are 
not natural to the milk itself, but depend upon the entrance of germs which are introduced either accidentally or intentionally after the milk is drawn. Thus that common phenomenon, the souring of the milk, is not due to any inherent tendency in the milk itself, but to the introduction of the lactic acid bacilli which split up the sugar of milk and produces lactic acid. The investigations of bacteriologists and chemists, supported by the work of practical experimenters, have established, during these recent years what appears to be a sound basis for the science of dairying.

It is only fair to say here, that the sum of original knowledge on this subject has received some valuable contributions through the investigations of the experts of the Canadian departments of agriculture and agricultural colleges. It may also be said that Canadian cheese-makers have led the van in applying the teachings of science to the practice of their art.

But we must not pursue this phase of the subject any further, or we shall get into technicalities which would neither be profitable nor interesting to this audience. It will be more in keeping with the aims and objects of the Court in arranging the course of lectures, of which the present is one, if we now proceed to consider the origin, status and possibilities of the dairy industry in Canada.

The early French settlers introduced cows from Brittany and no doubt made butter from their milk. It is quite likely that they made cheese also and that the 'Fromage raffine' still made on the Island of Orleans is a relic of their early efforts. Cheese of a more or less nondescript character was made for home use by the early settlers of Ontario, but neither the art nor the industry made any progress in Canada until the factory system was introduced in the year 1864. The first cheese factory was established in Oxford county, Ontario, by one Harvey Farrington, who came from New York State 
for the purpose. Another factory was started in Hastings county in 1866, and from that time forward the extension of the industry forged rapidly ahead in Ontario. The first cheese factory was established in the province of Quebec, in Missisquoi county, about the same time as the first ones in Ontarin, but there was very little development of the industry until after the year 1880 .

The dairy industry has not grown as much in New Brunswick or in Nova Scotia as one would expect to find in districts so well adapted for it. Fruit growing, lumbering and fishing have divided the attention of the farmers to some extent, and dairying does not prosper unless it is made the special business of the farm. There are, however, a number of successful cheese factories and creameries in these two provinces, and they supply the local demand for butter and cheese and have a considerable surplus for export to the West Indies. I was gratified to find, when I visited Bermuda and Jamaica a year or two ago, that the 'Bluenose' and the 'Evangeline' brands of butter and cheese were the most popular of any sold in those islands.

Co-operative or factory dairying was begun in Prince Edward Island in 1902, under the guidance of my predecessor in office, Dr. James W. Robertson. In a few years there were some 40 factories in operation and Prince Edward Island became recognized as a successful dairying province. It has been generally acknowledged that the prosperity of the island has been wonderfully quickened by the adoption of systematic dairy practices.

Following the trend of events rather than geographical sequence, let us now turn our attention to the West for a few moments. In Manitoba, organized dairying began to make headway about 1894, and there are now a fair number of cheese factories and creameries in that province. In what was then 
the territories of Assiniboia and Saskatchewan, there were at one time 14 creameries in active operation, but the reign of King Wheat has proved inimical to the growth of the dairy industry, and it has not been developed extensively in what is now the province of Saskatchewan.

Proceeding westward into Alberta, we find more favourable conditions, especially in that section of the province lying between Calgary and Edmonton, where the progress of the dairy industry has kept pace with the settlement of the country. Beginning in 1896, the increase has been steady and substantial, with the result that to-day there are 45 creameries and 8 cheese factories in the sunny province of Alberta. There is every indication that Northern Alberta will become one of the best dairy sections of Canada.

These two western provinces have been the scene of a unique and rather abrupt departure from the line which has generally been followed by governments in assisting agricultural effort. A few creameries had been started in the early nineties as private or co-operative ventures, but at the end of two or three years, they were, for various reasons, and without exception, acknowledged to be failures. The new settlers, who were depending almost wholly on dairying as a means of livelihood, were in a serious position, because, while it was possible for them to make butter on their farms, their facilities were very poor, and there was no way by which the individual farmer could find a profitable market for his butter at that time.

The Dominion Government came to the rescue, and the Dairy Commissioner was authorized by the Honourable the Minister of Agriculture to take over the management of the existing creameries, to advance sufficient money to pay off their pressing debts, and to make loans for the equipment of new creameries that would come under the same management. 
Confidence was at once restored and under expert supervision the business grew and prospered so that the Department of Agriculture was able, at the end of 1905, to give up the active control of a large number of creameries which had been assisted to a position of independence and stability. New markets had been found for the butter in the Orient and in the Yukon, and a reputation had been established that is of great value to the industry in that part of the country to-day. The money which was advanced to the creamery associations has all been repaid except a few trifling amounts.

The new provincial governments are following the policy adopted by the federal authorities, and with a modified plan, continue to foster the industry. Knowing the circumstances, as $I$ do, I have no hesitation in asserting that this action on the part of the government, call it paternalism if you like, saved what was then known as 'The Territories' from a most serious setback, and carried the early settlers over the most critical and trying period of their experience.

Crossing the Great Divide into British Columbia, we find a successful creamery business established at different points in the fertile Okanagan valley, along the Lower Fraser river, and on Vancouver island.

Thus we see that the dairy industry is well established in every province of the Dominion from the Atlantic to the Pacific. The total number of cheese factories and creameries in Canada at present is 4,355. Of this number, 1,284 are in the province of Ontario, and 2,806 are in Quebec, leaving 265 fairly evenly distributed among the other seven provinces. The factories in Ontario average much larger than those in the other provinces.

The first cheese was exported from Canada to Great Britain in 1864. The shipments grew year by year and reached the 
maximum in 1903, when the total value of the butter and cheese exported amounted to the sum of $\$ 31,667,561$.

The slight falling off in the quantity exported during the last year or two has been attributed to a decline of the industry, but the true reasons for it are much more satisfactory and are really a cause for congratulation. The large growth in our population and the increased purchasing power of the people generally, easily account for the decrease in the exports.

There is no reason why the dairy industry should not be largely extended in every province of the Dominion. I have visited every important dairy country in the world, except Siberia, and am bound to say none of them is better fitted by nature for successful dairying than Canada is. With a climate which produces healthy, vigorous animals, notably free from epizootic diseases, with a fertile soil for the growing of fodder crops and pasture, with abundance of pure water, and a plentiful supply of ice for all purposes of the dairy, we have almost ideal conditions, and advantages which should be of great assistance in holding a fair share of the world's trade in dairy products.

Great Britain is our chief market for butter and cheese, although we send comparatively small quantities to Newfoundland, Bermuda, the West Indies, British Guiana, Mexico and South Africa. We also sell some butter in the Orient, and of late years a small quantity has gone to Germany.

The quantity of butter and cheese annually imported into Great Britain is enormous. The value of the butter alone amounts to over $\$ 100,000,000$, of which the little kingdom of Denmark supplies nearly one-half. Siberia comes next and is credited with over $\$ 15,000,000$ worth, closely followed by Australia. Next in the order of their importance are, France, New Zealand, Sweden, The Netherlands, Canada, the United States and Argentina. Small and irregular quantities are 
received from some other countries. It will probably surprise many of you to hear that the dairymen of Iceland send occasional shipments of creamery butter to Scotland.

The value of the cheese annually imported into Great Britain is a little over $\$ 33,000,000$, of which Canada has the distinction of furnishing 72 per cent of the whole or 84 per cent of the kind which we make. The other countries from which supplies of cheese are obtained are New Zealand, The Netherlands, United States, France, Switzerland, Italy and Australia. These facts are important, especially in regard to butter, because they show us what a great field there is for a further extension of our butter trade. Canadian butter stands high in the British market, not only for its superior quality, but because our laws relating to its manufacture and sale are the most stringent of any country in the world, and are a standing guarantee of its absolute purity. I need hardly say that Canadian cheese easily ranks first in quality among the imports into Great Britain of the class to which it belongs.

The comparative food values of milk and cheese are becoming better known and as this appreciation grows, as it should, these products will enter more largely into our daily dietary than they do at present. A quart of good milk is said to be equal in food value to a pound of meat, and one pound of well ripened cheese contains as much nourishment as two and a-half pounds of the best beefsteak; therefore; millk at 12 cents a quart and cheese at 20 cents a pound are among the cheapest of foods, compared with the present prices. of other things.

The governments of Canada, both federal and provincial; have been liberal in their policies concerning the dairy in. dustry. It has been generally agreed that the provincial authorities should undertake all work which is educational in character, while the Dominion Government deals with 
questions pertaining to markets, transportation and cold storage, or what may be termed the commercial side of the industry. The Dominion Government also assumes the responsibility for the enactment and the administration of the laws relating to the manufacture, sale and exportation of dairy products.

All the provincial departments of agriculture, except Nova Scotia, have regularly organized dairy divisions. Dairy schools are maintained in Ontario, Quebec, New Brunswick and Manitoba. Experts are employed who visit the cheese factories and creameries during the working season, for the purpose of giving instruction to the cheese or butter makers and to advise with those in charge of factories on questions of general management. Canada was the first country in the world to adopt this system of factory instruction, and there are now nearly 100 of these experts employed by the different provincial governments. Much of our success in cheese-making can be attributed to this system of factory instruction.

The Dominion officials endeavour to keep in touch with the tendencies and requirements of the markets to which our butter and cheese are shipped, and to disseminate among the cheese and butter makers such information as may be acquired with that end in view.

A large staff of men are employed, under the Dairy and Cold Storage Commissioner, who watch and report on the handling of butter and cheese from the time it leaves the factory in Canada until it reaches the consumer in Great Britain. The information thus collected is passed on to those who may be interested, or who are responsible for the defects which have been noted, and as a result there is constant improvement being made, not only in the quality of the butter and cheese and in the appearance and style of the packages, but also in the services provided by the transportation com- 
panies. The cold storage services, both on land and sea, which were inaugurated through the initiative of the Department of Agriculture, at the head of which is the Hon. Sydney Fisher, who is our chairman this evening, have been of incalculable benefit to the dairying industries.

Ladies and Gentlemen, I have attempted in this brief sketch, to give you some idea of the importance and value of the dairying industries to Canada. I hope I have been suc cessful in some degree at least. 




Cornell University Library

SF 233.C2R8

The dairying industry,

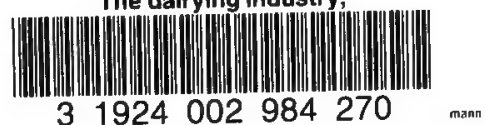




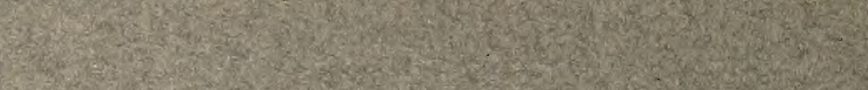

